\title{
A Brief Review: Application of Recycled Polyethylene Terephthalate in Asphalt Pavement Reinforcement
}

\author{
Mohamed Meftah Ben Zair ${ }^{1,2}$ D , Fauzan Mohd Jakarni ${ }^{1, *(\mathbb{D},}$, Ratnasamy Muniandy ${ }^{1}$ and Salihudin Hassim ${ }^{1}$ \\ 1 Department of Civil Engineering, Faculty of Engineering, Universiti Putra Malaysia, \\ 43400 UPM Serdang, Selangor, Malaysia; mzair84@gmail.com (M.M.B.Z.); ratnas@upm.edu.my (R.M.); \\ hsalih@upm.edu.my (S.H.) \\ 2 Department of Civil Engineering, Faculty of Engineering, Misurata University, Misurata, Libya \\ * Correspondence: fauzan.mj@upm.edu.my
}

check for updates

Citation: Ben Zair, M.M.; Jakarni, F.M.; Muniandy, R.; Hassim, S.

A Brief Review: Application of Recycled Polyethylene Terephthalate in Asphalt Pavement Reinforcement. Sustainability 2021, 13, 1303. https:// doi.org/10.3390/su13031303

Received: 17 October 2020 Accepted: 29 November 2020 Published: 27 January 2021

Publisher's Note: MDPI stays neutral with regard to jurisdictional clai$\mathrm{ms}$ in published maps and institutional affiliations.

Copyright: $(\odot 2021$ by the authors. Licensee MDPI, Basel, Switzerland. This article is an open access article distributed under the terms and conditions of the Creative Commons Attribution (CC BY) license (https:// creativecommons.org/licenses/by/ $4.0 /)$.

\begin{abstract}
Plastic is considered one of the most significant industrial inventions of this era due to its excellent properties, which lend well to many manufacturing applications. These days, there are tons of Polyethylene Terephthalate (PET) waste products that are generated around the world. This waste presents a real environmental hazard because PET is not biodegradable. This paper delineates the physical and chemical properties of PET to justify its use as an additive and aggregate replacement in the manufacture of asphalt mixtures. Furthermore, discusses details of PET-modified asphalt mixture by a dry and wet process with sufficient information to better understand the mixture. Several critical matters are investigated, such as asphalt modification to increase resistance to fatigue, rutting deformation, and moisture sensitivity. These results are important for determining the factors that significantly improve pavement mixture characteristics. The findings show that the addition of PET to asphalt mixtures yielded very promising results. PET enhanced the mechanical properties, the durability, and the long-term sustainability of the pavement. Finally, using PET waste as an additive in asphalt mixtures could serve as an environmentally friendly method to dispose of PET waste while simultaneously producing high-quality pavements.
\end{abstract}

Keywords: asphalt binder; polyethylene terephthalate; fatigue life; rutting deformation; moisture sensitivity

\section{Introduction}

A world without plastics or synthetic organic polymers sounds impossible today. However, their production and use on a vast scale only dates back to 1950 [1]. Plastics are different types of synthetic or semi-synthetic materials used in various growing product range. The rapid growth that ensued in the production of plastics is unprecedented, surpassing any other human-made products [2,3]. The main concern, as stated in the Paris Climate agreement, has recently been to enhance plastic design and production to promote its reuse, repair and recycling, to isolate plastics production from fossil resources and minimize emissions of greenhouse gases [4]. Many synthetic plastics today are made from petroleum and natural gas [5]. The biggest demand for plastics is packaging, an application whose production has been accelerated by global change from reusable to single-use products. The plastic proportion by mass in municipal solid waste has raised from 1 to $10 \%$ from 1960 to 2005 in high- and middle-income countries [6].

Plastic is considered as one of the most significant industrial inventions of this era. It has excellent properties such as cheap costs, high durability, low-density durability, high strength relative to weight, and easy to operation and shaping $[7,8]$. The world's plastic production has grown dramatically and is predicted to exceed more than 34 billion metric tons by 2050 [1]. In Europe, the main applications of plastics manufacturing could be noted in the packaging industry $39.9 \%$, construction $19.8 \%$ the automation industry $9.9 \%$, and electronics $6.2 \%$ [2]. Although the manufacture of plastics in its various forms 
cannot be stopped, recycling may be a better disposal solution to the hazardous waste plastics that affect the environment [9-11]. Throughout the world, there are millions of tonnes of plastic waste that are generated in various forms. Almost $25 \%$ of plastic waste is recycled and reuse again in different fields. However, plastic recycling and regeneration are also inadequate, and millions of tonnes disposed of in landfills and the other often their way find into soil, oceans, and rivers every year [12]. This proportion of recycled plastic can be raised by converting waste plastic material into items beneficial for housing and constructing [13].

There are two plastic groups-namely, thermoset plastics and thermoplastics. Thermoset plastics are melted by heating and then solidify afterwards. The process in which the plastic changes from liquid to solid state is irreversible. Thermoplastics can be frequently melted and strengthened by heating and cooling [14]. Polyethylene Terephthalate (PET) is one of the most significant modern plastics to be invented. PET is a semi-crystalline polymer, with mechanical properties that depend on crystallinity level [15]. This material is considered to be a thermoplastic polyester material, which is now used globally [16]. The beverage industry has been using PET to produce drink bottles since the 1980s. More than 700 million pounds of this material has been consumed in 1987 [17]. The global production of PET was amounted to $41.56 \mathrm{Mt}$ in 2014, with an expected growth of $70 \%$ by 2020 . China is considered the largest manufacturer with a percentage of $27 \%$; then Europe, $17 \%$; North America, 17\%; and South America, 7\% [18]. Nowadays, because of the favorable physical and chemical properties of PET, this material is used as packaging and container material (i.e., carbonated drinks bottles, jars, pipes, sporting goods, etc.) [19]. Figure 1 outlines the research flow for this current work.

\section{Recycled Polyethylene Terephthalate (PET) - Asphalt Mixture}

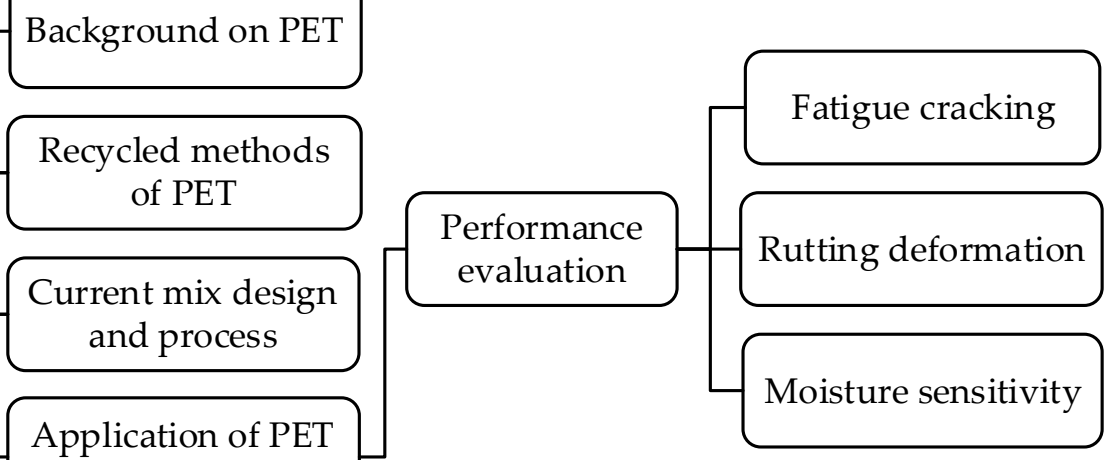

Figure 1. Research flow.

\subsection{Waste Polyethylene Terephthalate (PET)}

These days, there are tons of PET waste products that are generated around the world. This waste presents a real environmental hazard because PET is not biodegradable [20]. Currently, modern techniques to dispose of PET waste and polymers include waste landfills, open burning, and recycling. However, these techniques do not help environmental protection efforts. The waste landfill is the simplest and oldest waste disposal strategy in the world, but it has led to many issues such as land occupation, groundwater pollution, unsafe disposal, and wastage of resources. Hence, reprocessing (recycling) these plastic materials seems to be the best option. Recycling is a convincing and logical strategy for reusing PET waste. Nevertheless, recycling is essentially limited due to its high cost [21]. As shown in Figure 2, there are three specific environmental advantages of using PET in new pavement construction. 


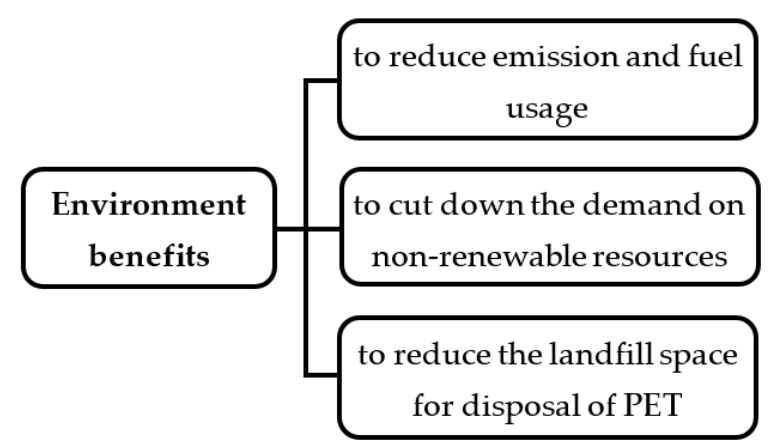

Figure 2. Environmental benefits of using PET for new pavement construction.

Figure 3 illustrates the accumulated quantity of the generated plastic waste and disposed 1950 to 2015 and the expected quantity by 2050. Almost 16\% of this quantity was recycled up to 2015 . It is predicted that up to $33 \%$ of the waste plastic will be recycled by 2050. Even if this prediction becomes true, the quantity of unrecycled plastic waste would leave much to be desired [1].

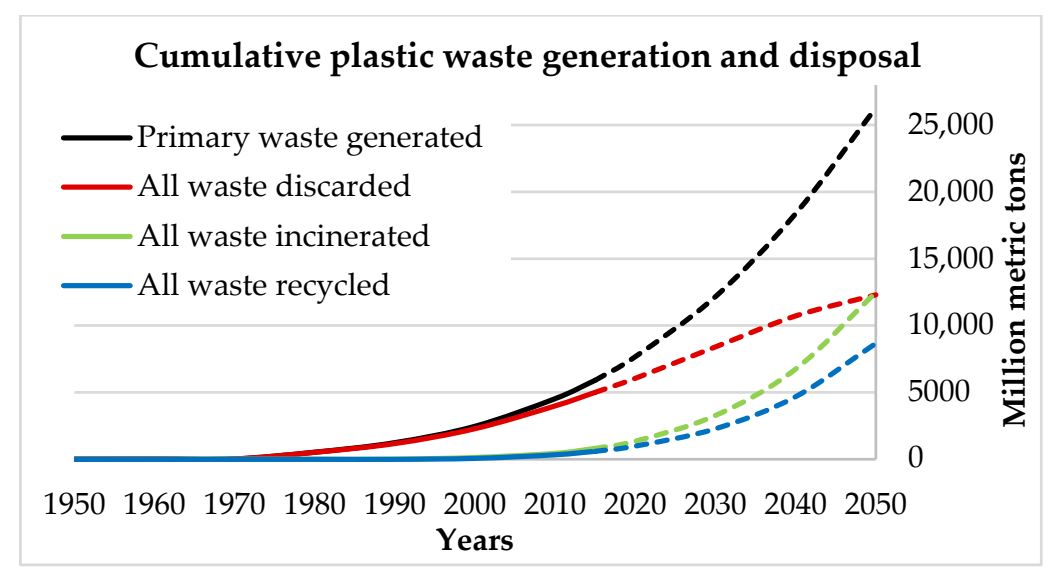

Figure 3. The accumulated quantity of the generated plastic waste and Disposed 1950 to 2015 and the expected quantity by 2050 [1].

\subsection{Methods for Recycling Polyethylene Terephthalate Waste}

The most practical methods to recycle Polyethylene Terephthalate are mechanical and chemical. The mechanical recycling of PET will decrease the quality of the recycled PET because it involves adhesive contaminants. Additionally, the chemical recycling of PET has a higher cost than mechanical recycling because the former must use chemicals such as catalysts at a certain temperature and at high pressure [22]. Mechanical recycling is also termed physical recycling; this process re-processes PET material by melting extrusions of the material after separating them from their integrated contaminants. It mostly involves the following processes and treatments: (1) insulating the PET from other plastic materials, (2) washing the filth and other contaminants followed by drying, (3) grinding the PET particles to reduce the particle size before reuse, (4) Heat extrusion, and (5) shaping and grinding the PET products. Physical recycling is simpler to apply and generally requires lesser effort than chemical recycling $[23,24]$.

Chemical recycling is an alternative to the physical recycling method. This method chemically polymerises or degrades PET waste before re-use. Many chemical recycling chemical processes can be used, such as hydrogenation, glycolysis, aminolysis, methanolysis, and hydrolysis [17,24]. Depending on the chemical depolymerisation process of PET post-consumer, the corresponding terephthalic acid (TPA) or ethylene glycol can be produced from the yield resulting from aminolytic chain cleavage $[17,25]$. The depolymerisation of PET waste material can be accomplished using several types of amines, for 
example, polyamines, ethanolamine, allylamine, and tri-ethanol amine. The aminolysis response is applied to manufacture PET products such as plasticisers and rigid polyurethane foams $[17,26]$.

\subsection{Physical and Chemical Properties of PET}

Virgin PET is a superior material for certain applications. This material has several excellent characteristics, such as good tensile strength, reasonable thermal stability, chemical resistance, processing capability, color capability, and clarity [27]. It can be formed by pressures and at normal temperatures. PET can be created from petroleum hydrocarbons, from the reaction between ethylene glycol and Terephthalate acid, as shown in Figure 4 [28]. The basic physical and chemical properties of commercially-used PET plastics are indicated in Table 1 [27].

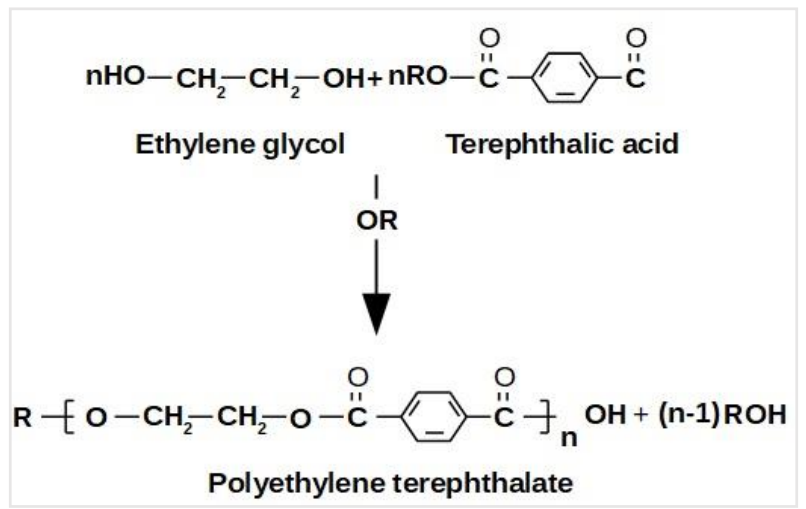

Figure 4. PET produced from the reaction between ethylene glycol and terephthalic acid.

Table 1. Physical and chemical properties of PET [27].

\begin{tabular}{ccc}
\hline Property & Test Method & Value (Unit) \\
\hline Molecular weight (of repeating unit) & - & $192\left(\mathrm{~g} \mathrm{~mol}^{-1}\right)$ \\
Mark-Houwink parameters & - & $\mathrm{k}=3.72 \times 10^{-2}\left(\mathrm{~mL} \mathrm{~g}^{-1}\right) \mathrm{a}=0.73$ \\
Weight-average MW & - & $30,000-80,000\left(\mathrm{~g} \mathrm{~mol}^{-1}\right)$ \\
Density & - & $1.41\left(\mathrm{~g} \mathrm{~cm}^{-3}\right)$ \\
Glass transition temperature & $(\mathrm{DSC})^{1}$ & $69-115\left({ }^{\circ} \mathrm{C}\right)$ \\
Melting temperature & $(\mathrm{DSC})^{1}$ & $265\left({ }^{\circ} \mathrm{C}\right)$ \\
Heat of fusion & (DSC) & $166(\mathrm{~J} / \mathrm{g})$ \\
Breaking strength & Tensile & $50(\mathrm{MPa})$ \\
Yield strain & - & $1700(\mathrm{MPa})$ \\
Impact strength & Tensile & $4(\%)$ \\
Water absorption (after $24 \mathrm{~h})$ & ASTM D256-86 & $90(\mathrm{~J} \mathrm{~m}-1)$ \\
\hline
\end{tabular}

${ }^{1}$ Differential scanning calorimetry (DSC).

\section{Performance of PET Modified Asphalt Binder}

Researchers have investigated the benefits of using waste materials in the construction industry, to better manage waste and to enhance the quality of construction materials $[29,30]$. Currently, several waste materials, such as waste glass, plastic, tires, etc., are used to improve the construction of various pavement layers, including the asphalt surface [31]. Asphalt pavements will be exposed to deterioration after construction, due to traffic loading activity and climatic conditions. This process can be delayed if good materials are used in the construction phase. Usually, materials that used as a modifier of asphalt binder have better performance than conventional ones [32]. According to Mashaan et al. [33], asphalt binder modification provides several benefits such as 
- A sufficient increase in the consistency of the asphalt pavement to prevent plastic deformation at high temperatures;

- Enhanced asphalt binder elasticity and flexibility to avoid loss due to chipping or cracking at low temperature;

- Increased adhesion between asphalt binder and aggregate; improved ageing resistance and homogeneity, and high thermal stability, which helps decrease the stiffening and initial ageing of asphalt binders during mixing and road construction.

Recycled PET can be used as an improved modifier for asphalt binders. This application could be counted as a method to reuse PET waste and in turn, addresses potential environmental risks and reduces construction costs that would result if polymers were used in the asphalt mixtures $[23,34,35]$. Moreover, the positive effects of PET have been proven, such as providing high-temperature characteristics for the asphalt mixture [36]. Nevertheless, PET is not always effective at increasing asphalt binder elasticity, especially during dramatic and unexpected drops in temperature. This condition degrades the intermediateand low-temperature characteristics of the asphalt binder [35]. In order to investigate the impact of PET on asphalt binder properties, PET was blended with the asphalt binder. The progressive addition of PET has been shown enhancing in the consistency of the binder and increased its elastic behavior. However, the increase in viscosity of modified binder leads to higher mixing and compaction temperatures. Although this is not economic in the short term, it can produce roads with less maintenance requirements. The addition of PET has reduced modified asphalt binder oxidation and has proved to be promising in anti-ageing action [37].

\section{Design Methods}

There are two ways to blend plastic with asphalt mixtures: (1) dry and (2) wet. The dry process requires adding the PET in the final segment of the mixing process and after introducing and incorporating the asphalt binder with the aggregate, as shown in Figure 5. Meanwhile, the wet process combines the PET material with the asphalt binder and blends it. Then, a "plastic-modified asphalt binder" is applied to the heated aggregates, as shown in Figure 6. However, studies have noted that it is not feasible to introduce PET as an additive into asphalt mixtures via the wet process because PET has a melting point of around $250^{\circ} \mathrm{C}$, so it is quite difficult for it to maintain a homogenous mixture. The mixture will also tend to separate from the asphalt binder [38]. On the contrary, in a study conducted by this process. The results showed that the micronized PET mixtures could improve the mechanical performance of asphalt mixtures if compared to conventional ones, due to the fine PET particles which are easy to mix with asphalt binder [39]. Meanwhile, in the dry process, it has been proved to help enhance the performance of asphalt mixtures [35,40]. Table 2 presents the summary of PET blending process by the dry and wet method.

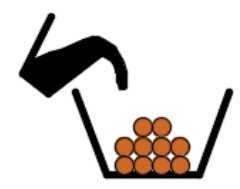

Asphalt binder + Aggregate

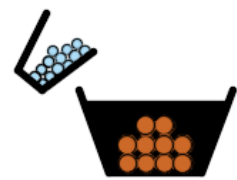

PET + Aggregate + PET

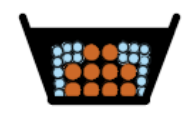

PET- asphalt mixture

Figure 5. Dry process.

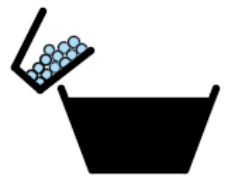

PET + Asphalt binder

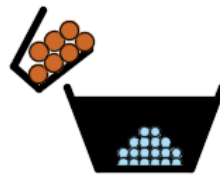

Aggregate + PET + asphalt binder

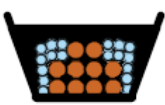

PET- asphalt mixture

Figure 6. Wet process. 
Table 2. Blending process.

\begin{tabular}{ccc}
\hline Mixing Mode & Binder Grade & Reference \\
\hline Dry Process & $80-100$ & {$[36,40-42]$} \\
Dry Process & $60-70$ & {$[38,43,44]$} \\
Dry Process & PG58-16 & {$[45]$} \\
Wet Process & $40-50$ & {$[46]$} \\
Wet Process & $50-70$ & {$[39]$} \\
Wet Process & $60-70$ & {$[47,48]$} \\
Wet Process & $80-100$ & {$[49]$} \\
\hline
\end{tabular}

\section{PET Waste as Additive in Asphalt Mixtures}

This section investigates the differences in the mechanical properties (e.g., fatigue damage, rutting deformation, and moisture sensitivity) of asphalt mixtures as a result of adding recycled PET waste. These properties are derived from the results of past investigations $[38,45,49]$. In previous studies, PET waste material was mostly applied to asphalt mixtures using the dry process [34] or used as a replacement to the fine aggregates in the mixture to enhance pavement resistance to permanent deformation [50]. The PET was also added to asphalt mixtures using the wet process to decrease moisture sensitivity and to increase resistance to fatigue [39]. Also, PET has also been used as an asphalt binder modifier to obtain high resistance to fatigue and permanent deformation [51]. Additionally, the aminolysis product of PET has also been used to modify the asphalt binder, while proving to be a good anti-stripping agent [16].

\subsection{Laboratory Fatigue of PET Modified Asphalt Mixtures}

Fatigue cracking is one of the significant damages to asphalt pavements that lead to failure. Because repetitive traffic loading could cause pavements to be prone to fatigue due to the reduction in strength, stiffness, and ending in fracture [52-54]. Therefore, the primary attribute that determines the service life of the pavement is fatigue life [55]. The asphalt pavement components become strained when subjected to cumulative stress and tension. These strains are elastic, viscoelastic, or plastic. Tensile plastic strains reduce fatigue life and cause the quality of the asphalt pavement to deteriorate [56]. Several factors affect fatigue life behavior, such as asphalt binder type, filler content, stiffness, air void percentage and asphalt content. Additional factors that also have been noted to affect fatigue performance of some mixtures include the angularity and gradation of aggregate and temperature of construction. The lack of adequate cohesion between two different pavement layers causes layer interface separation. This inadequate bonding contributes to not homogeneous structural movement, which inevitably shortens the life cycle of the asphalt pavement due to surface slippage and cracking from the bottom of the upper separated asphalt pavement layer [57]. Table 3 summarizes the fatigue performance of asphalt mixtures that have been added with PET waste.

Moghaddam et al. [36] studied the fatigue characteristic of an SMA mixture by introducing PET particles. Indirect Tensile Fatigue Test (ITFT) results are reported for each percentage of PET content. Figure 7 presents the relationship between stress, or strain and fatigue life (Nf). The findings indicate that the addition of a high amount of PET to the asphalt mixtures improved the fatigue life of the pavement compared to traditional mixtures. The high fatigue life could be attributed to certain causes such as the improved elastic property of the PET-reinforced asphalt mixture and stress reduction due to the addition of the PET particles. In another investigation, Moghaddam, et al. [41] evaluated different percentages of PET waste. The researchers concluded that because PET particles have a high melting temperature, the particles would not melt and would still be rigid in the asphalt mixture. The study found that fatigue life increased by increasing the percentage of PET. Also, a high level of PET improved the mixture's flexibility. Additionally, the crack creation and propagation in the asphalt mixture was delayed compared to conventional mixtures. Modarres and Hamedi [38] observed the impact of recycled PET particles on 
the fatigue life of asphalt mixtures at 5 and $20{ }^{\circ} \mathrm{C}$ and the results have been shown in Figure 8 based on at first and second fatigue life definition (N1\&N2). They found that the PET-modified asphalt mixture had improved fatigue properties and flexibility compared to the traditional mixture, at 5 and $20^{\circ} \mathrm{C}$. Additionally, it was noted that fatigue life increased when the test temperature was reduced. In another study, Mohd et al. [58] investigated the impact of adding recycled PET as a replacement for the fine aggregates in asphalt mixtures based on the change in fatigue properties. They noted that the asphalt mixture with $5 \%$ and $15 \%$ PET had more resistance to fatigue damage than traditional asphalt.

Table 3. The fatigue performance of PET waste-added asphalt mixtures.

\begin{tabular}{|c|c|}
\hline Author/Year & Main Finding \\
\hline $\begin{array}{l}\text { Moghaddam } \\
\text { et al. (2012) }\end{array}$ & $\begin{array}{l}\text { PET passed a sieve of } 2.36 \mathrm{~mm} \text {; Fatigue test at three stress levels }(250 \mathrm{kPa}, 350 \mathrm{kPa} \text {, and } 450 \mathrm{kPa}) \text { at } 20{ }^{\circ} \mathrm{C} \text {. Added } \\
\text { high percentages of PET to asphalt mixtures and observed improved fatigue life compared to traditional } \\
\text { mixtures. For example, fatigue life increased to } 124.8 \% \text { at } 250 \mathrm{kPa} \text { stress level using } 1 \% \text { PET when the number of } \\
\text { load cycles to failure (Nf) increasing from } 27,571 \text { cycles to } 61,981 \text { cycles. }\end{array}$ \\
\hline $\begin{array}{l}\text { Moghaddam } \\
\text { et al. (2013) }\end{array}$ & $\begin{array}{l}\text { PET passed a sieve of } 2.36 \mathrm{~mm} \text {; Indirect tensile fatigue test at three stress levels }(250,350 \text {, and } 450 \mathrm{kPa}) \text { at } 20^{\circ} \mathrm{C} \text {. } \\
\text { The mixtures with a PET particle content of up to } 1 \% \text { had the highest fatigue life, reaching double that of } \\
\text { conventional mixtures at lower stress levels. }\end{array}$ \\
\hline $\begin{array}{l}\text { Modarres and } \\
\text { Hamedi (2014) }\end{array}$ & $\begin{array}{l}\text { PET particles }(0.425-1.18 \mathrm{~mm}) \text {; Fatigue test at } 5 \text { and } 20^{\circ} \mathrm{C} \text {. PET-modified asphalt mixture with content up to } 10 \% \\
\text { had improved fatigue properties and flexibility. Additionally, the findings showed that the fatigue life increased } \\
\text { with a reduction in the test temperature. }\end{array}$ \\
\hline $\begin{array}{l}\text { Mohd et al. } \\
\text { (2016) }\end{array}$ & $\begin{array}{l}\text { PET as fine aggregate replacement }(3.36-1.18 \mathrm{~mm}) \mathrm{mm} \text {; Indirect tensile fatigue test. It was noted that the asphalt } \\
\text { mixture with } 5 \% \text { and } 15 \% \text { PET content showed more resistance to fatigue damage. }\end{array}$ \\
\hline $\begin{array}{l}\text { Silva et al. } \\
\quad(2017)\end{array}$ & $\begin{array}{l}\text { Micronized PET; Fatigue test. Asphalt binder modified with micronized PET had a } 25 \% \text { improved fatigue life } \\
\text { compared to that of the traditional mixtures. }\end{array}$ \\
\hline $\begin{array}{l}\text { Dehghan and } \\
\text { Modarres } \\
\quad(2017)\end{array}$ & $\begin{array}{l}\text { PET fibers added at different lengths }(1 \mathrm{~cm} \text { and } 2 \mathrm{~cm}) \text { and a diameter of } 30 \mu \mathrm{m} \text {; crumb PET }(0.425-1.180 \mathrm{~mm}) \text {; } \\
4 \text {-point bending test was conducted via a universal testing machine at initial strain levels }(300,500 \text {, and } \\
700 \text { microstrain). PET fiber and crumb PET, if introduced at a suitable percentage, could enhance resistance } \\
\text { against fatigue damage. }\end{array}$ \\
\hline
\end{tabular}

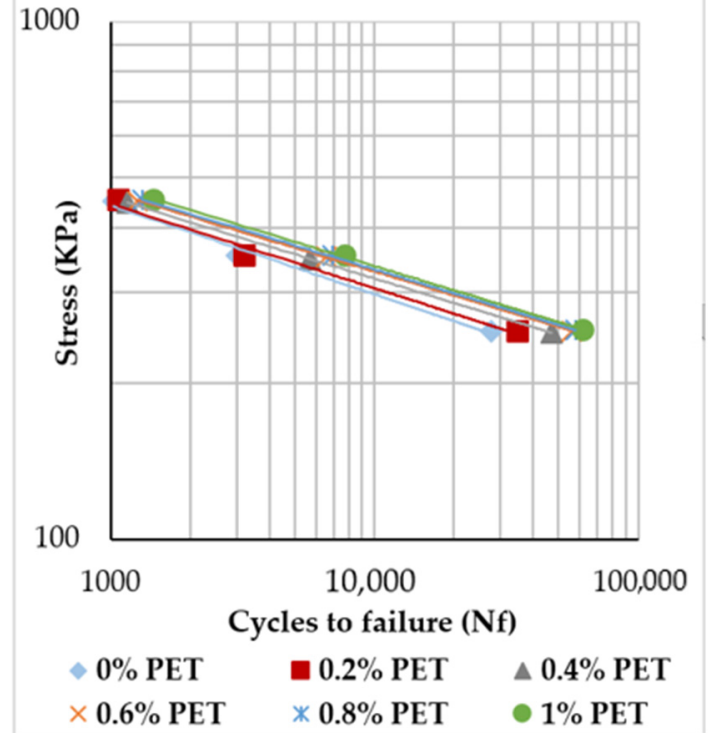

(a)

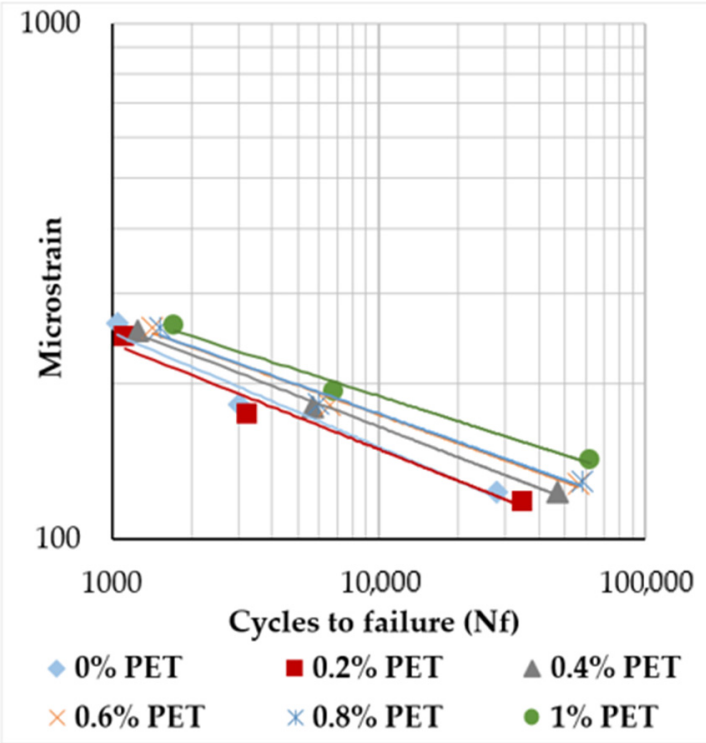

(b)

Figure 7. (a) Relationship between fatigue life (Nf) and stress at different \% of PET; (b) Relationship between fatigue life (Nf) and strain at different \% of PET [36]. 


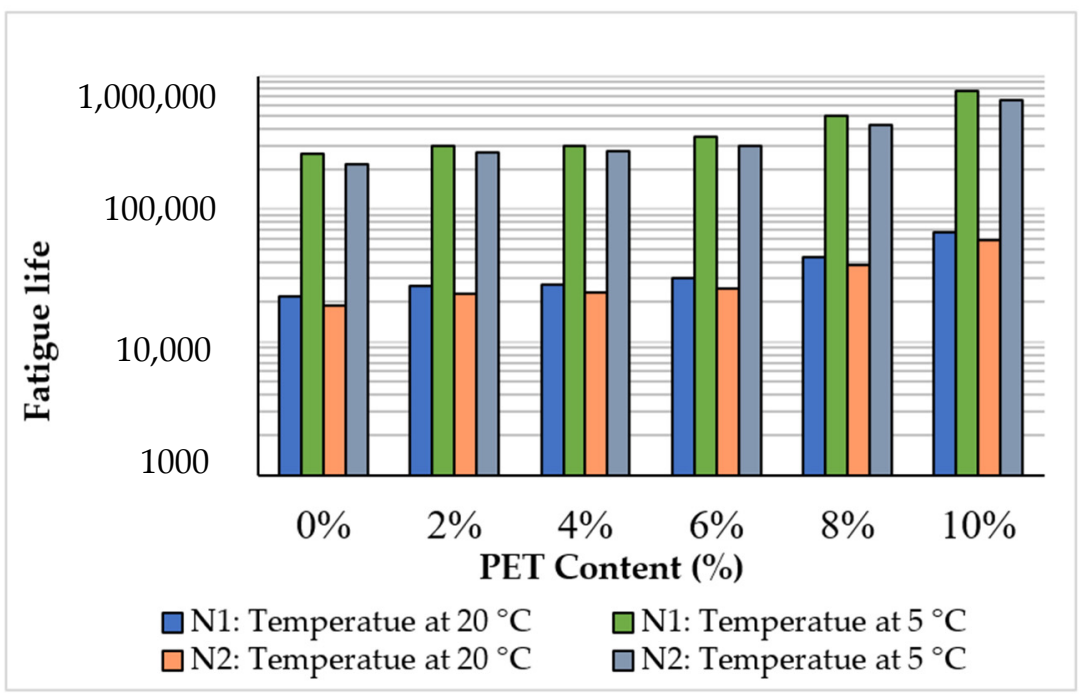

Figure 8. Result of fatigue life of asphalt mixtures at first and second fatigue life definition (N1\&N2) at 5 and $20^{\circ} \mathrm{C}$ [38].

Additionally, Silva et al. [39] assessed an asphalt mixture reinforced with micronized PET. The impact of PET on fatigue properties showed that the Asphalt binder modified with micronized PET had a $25 \%$ improved fatigue life compared to that of the traditional mixture. Hence, fatigue cracking was also reduced. Dehghan and Modarres [43] examined the effect of recycled PET fibers on the fatigue life of asphalt mixture. Figure 9 shows the effect of $1 \& 2$-cm fibers on the fatigue life of HMAs at initial strain level of (300, 500 and 700 ) microstrain. The results show that the optimum fatigue was achieved with $1 \%$ and $2 \%$ PET fiber with 1 and $2 \mathrm{~cm}$ lengths, and crumb PET, respectively. The addition of fiber content up to $1.5 \%$ increased the fatigue life, then the increase in fiber content to $2.0 \%$ had a reverse impact and result in a decrease in fatigue life for both lengths studied at initial stain level of 300 microstrain. Moreover, the mixture with $2 \mathrm{~cm}$ fiber length performed much better than the mixture with the $1 \mathrm{~cm}$ fiber length at initial stain levels of (500 and 700) microstrain at all PET fiber content, except $0.5 \%$.

Previous studies have shown that the incorporation of PET into the asphalt mixture has increased the elasticity of the mixture, which makes the mixture more flexible and preventing cracks initiation and spread in mixtures because of cyclic loading [36,41]. Besides, adding a higher content of PET contributed to lower stiffness and longer fatigue life. This may be due to the higher energy absorbency of the PET particles which resulted in better performances against replicated loading conditions [38].

\subsection{Rutting Performance of Asphalt Mixtures Modified with PET Waste}

Rutting deformation is one of the most basic damages affecting asphalt mixtures. This damage influences the serviceability of asphalt pavements [59]. Load from vehicle wheels might result in rutting deformation such as imprints, paths, and ruts [60]. Several factors cause rutting deformation such as the type and gradation of aggregate, the binder type and content, the air void in the asphalt mixture, temperature, and the applied loading on the pavement layers [59,61]. Besides, different traffic conditions (e.g., slow traffic, heavy load, and high traffic density) also lead to different rutting performance [62,63]. Moreover, the lower values of the softening point of the unmodified binder produced asphalt pavement layers to be more susceptible to rutting deformation during the summer season [64]. As shown in Figure 10, there are two types of rutting deformation in a flexible pavement: (i) consolidation rutting, which occurs along the wheel path with excessive consolidation of the pavement due to reduced air voids in the asphalt pavement layers; and (ii) permanent deformation, which happens due to the base or subgrade. The top two inches of the asphalt 
pavement is more sensitive to rutting deformation [65]. The rutting performance of PET particle-reinforced asphalt mixtures is shown in Table 4.

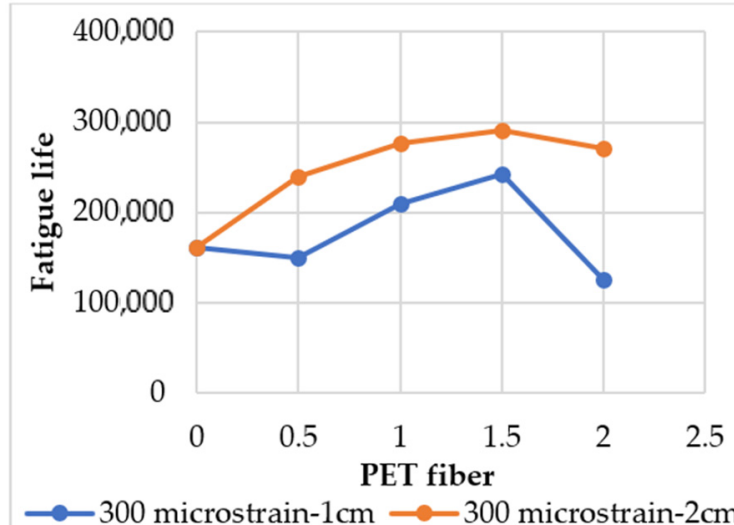

(a)

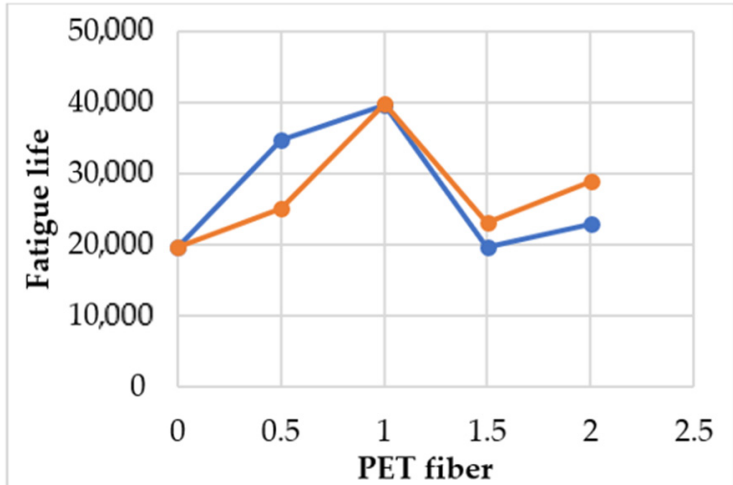

$\longrightarrow 500$ microstrain- $1 \mathrm{~cm} \longrightarrow 500$ microstrain- $2 \mathrm{~cm}$

(b)

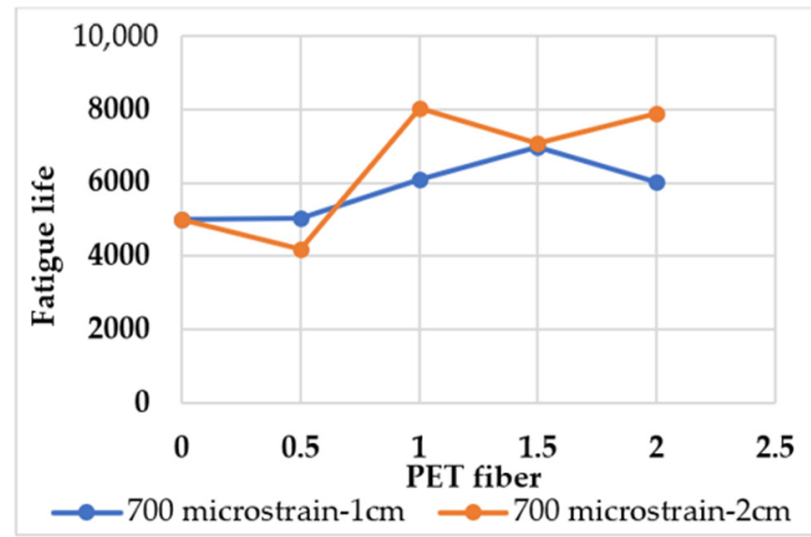

(c)

Figure 9. (a) Fatigue life at initial strain of 300 microstrain with PET length $1 \mathrm{~cm}$ and $2 \mathrm{~cm}$; (b) Fatigue life at initial strain of 500 microstrain with PET length $1 \mathrm{~cm}$ and $2 \mathrm{~cm}$; (c) Fatigue life at initial strain of 700 microstrain with PET length $1 \mathrm{~cm}$ and $2 \mathrm{~cm}$ [43].

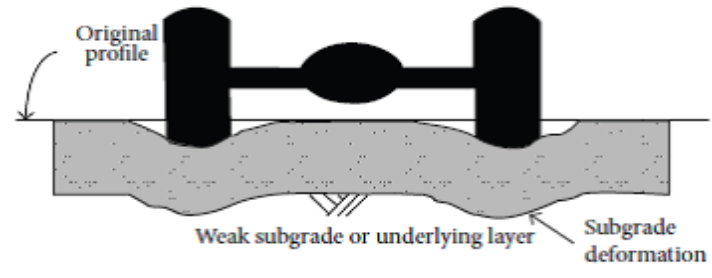

(a)

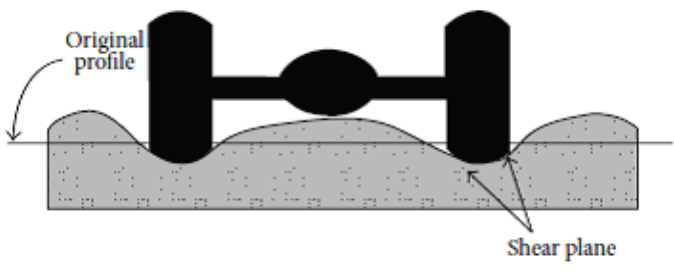

(b)

Figure 10. (a) Consolidations rutting in flexible pavement; (b) Instability rutting in flexible pavement [65].

Ahmadinia et al. [40] found that adding PET to stone mastic asphalt (SMA) mixtures produced less permanent deformation (rutting) than unmodified mixtures and increased with adding a high content of PET. The same result was reported by Taherkhani and Arshadi [45] as displayed in Figure 11. The result shows the values of MQ versus PET content. Moreover, the study showed that the fine-graded of PET particles yielded more significant performance than the coarse-graded PET particles. Mohd et al. [50] studied the rutting deformation of and asphalt mixture with the addition of ( $5 \%$ to $25 \%$ PET) by 
weight of asphalt. At $20 \%$ PET content specifically, the study found that rutting resistance and recovery significantly improved compared to the unmodified traditional mixture. Therefore, the addition of PET particles to replace the fine aggregate in the asphalt yielded favorable results. Moghaddam et al. [42] assessed the rutting characteristics of asphalt pavement with PET flakes as an additive. Based on the permanent strain of all specimens under different stress levels and temperatures, a higher PET content resulted in mixtures with better resistance to rutting deformation. The reason is that PET is a semi-crystalline material. The study concluded that the addition of PET particles enhanced the properties of the asphalt mixture. First, the melted PET particles improved the adhesion between the asphalt binder and the aggregate. Secondly, solid PET particles could absorb some of the impact from applied loading.

Table 4. The rutting performance of a PET particle-modified asphalt mixture.

\begin{tabular}{|c|c|}
\hline Author/Year & Main Finding \\
\hline $\begin{array}{l}\text { Ahmadinia } \\
\text { et al. (2012) }\end{array}$ & $\begin{array}{l}\text { PET particles size } 1.18 \mathrm{~mm} \text { with Portland Cement in (SMA); wheel tracking test. The minimum rut depth of the } \\
\text { mixture was obtained with } 4 \% \text { PET. As a result, a stiffer mixture and improved resistance to rutting deformation } \\
\text { were achieved. }\end{array}$ \\
\hline $\begin{array}{l}\text { Mohd et al. } \\
\quad(2013)\end{array}$ & $\begin{array}{l}\text { PET particles size }(1.18-2.36 \mathrm{~mm}) \text { With Cement Portland; Repeated load axial test. Modified mixtures, } \\
\text { specifically at } 20 \% \text { PET content, exhibited better rutting resistance and recovery than the unmodified } \\
\text { control mixture. }\end{array}$ \\
\hline $\begin{array}{l}\text { Moghaddam } \\
\text { et al. (2013) }\end{array}$ & $\begin{array}{l}\text { PET passed a sieve of } 2.36 \mathrm{~mm} \text {; Dynamic creep test under different stress levels ( } 300 \text { and } 400 \mathrm{kPa} \text { ), at different } \\
\text { temperatures } 10{ }^{\circ} \mathrm{C}, 25^{\circ} \mathrm{C} \text {, and } 40^{\circ} \mathrm{C} \text {. Asphalt mixtures with more PET content had better resistance against } \\
\text { permanent deformation. }\end{array}$ \\
\hline $\begin{array}{l}\text { Moghaddam } \\
\text { et al. (2014) }\end{array}$ & $\begin{array}{l}\text { PET passed a sieve of } 2.36 \mathrm{~mm} \text {; Static and dynamic load test. Modified mixtures under static loading had more } \\
\text { permanent deformation than the control while under dynamic loading, the samples deformed and then } \\
\text { underwent some recovery time to return to its original state. }\end{array}$ \\
\hline $\begin{array}{r}\text { Ziari } \\
(20\end{array}$ & $\begin{array}{l}\text { Small particles of PET }(10 \times 2.5,20 \times 2.5,30 \times 2.5 \mathrm{~mm}) \text {; Dynamic creep test. The results showed that PET } \\
\text { particles could absorb the stresses resulting from dynamic load and delayed rutting deformation. }\end{array}$ \\
\hline $\begin{array}{l}\text { Teherkhani and } \\
\text { Arshadi (2017) }\end{array}$ & $\begin{array}{l}\text { Coarse PET particles }(1.18-2.36 \mathrm{~mm}) \text { and fine PET particles }(0.297-0.595 \mathrm{~mm}) \text {; Marshall Quotient test. The results } \\
\text { revealed that MQ increases with an increase in PET content up to } 4 \% \text { for mixtures containing fine and } \\
\text { coarse-graded PET particles, after which the tendency reverses. }\end{array}$ \\
\hline $\begin{array}{l}\text { El-naga and } \\
\text { Ragab (2019) }\end{array}$ & $\begin{array}{l}\text { Small particles of PET; Wheel tracking test. PET particles added in any percentage helped reduce the rut depth } \\
\text { of the asphalt mixture. }\end{array}$ \\
\hline $\begin{array}{l}\text { Moghaddam } \\
\text { et al. (2015) }\end{array}$ & $\begin{array}{l}\text { PET passed a sieve of } 2.36 \mathrm{~mm} \text {; Adaptive neuro Fuzzy inference system. The rutting performance of the asphalt } \\
\text { mixture was highly affected by the PET content and environmental conditions. Furthermore, accumulative } \\
\text { strain decreased after PET was added to the asphalt mixture. }\end{array}$ \\
\hline
\end{tabular}

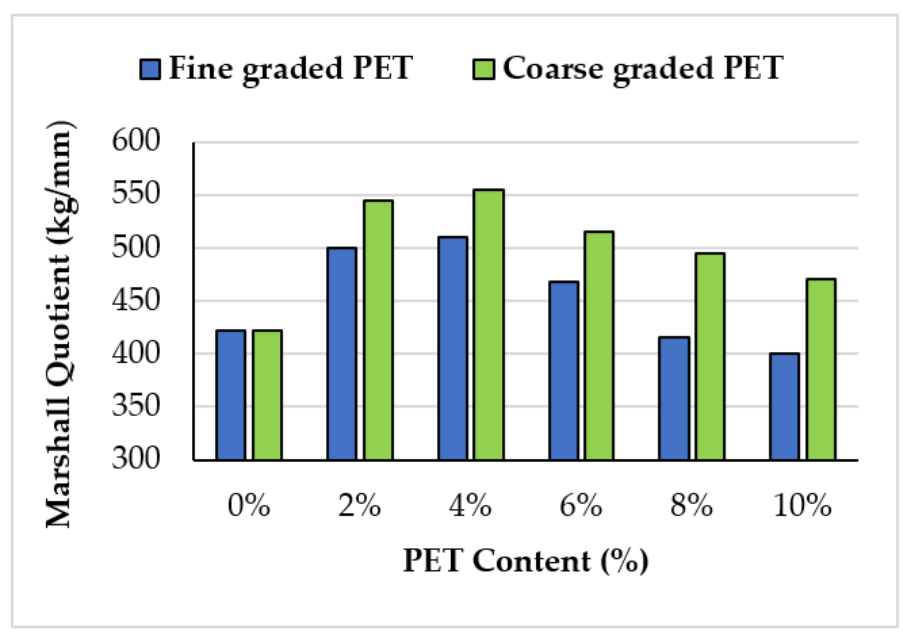

Figure 11. Marshall Quotient values versus PET content [45].

Moghaddam et al. [34] evaluated rutting performance under both static and dynamic loads. Figure 12 shows the results of static and dynamic tests, respectively. Under static 
loading conditions, mixtures with higher PET content showed higher rutting deformation than the control and the results indicated that the modified mixtures did not perform as well under static applied loads except the modified mixtures 1\% PET have the lowest amount of permanent deformation. On the other hand, the permanent deformation decreases under dynamic loads compared to the control mixture and the mixtures modified with PET and the deformed mixture still recovered back to its original state.

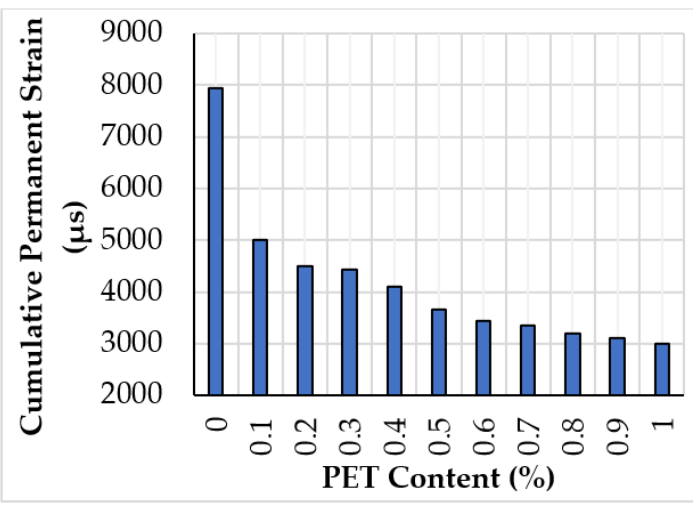

(a)

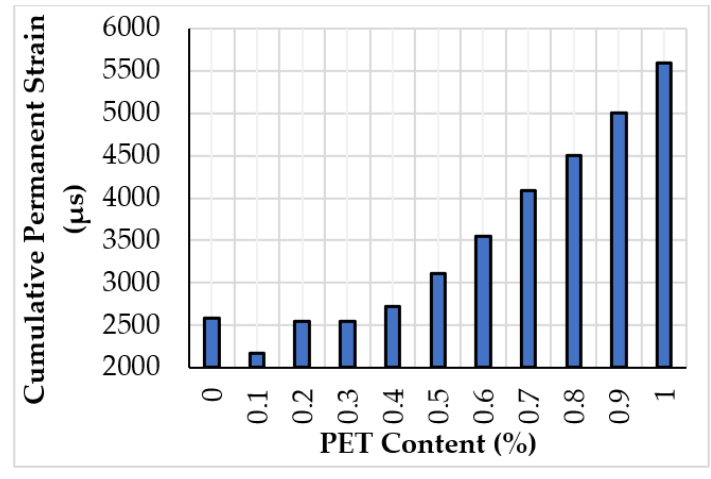

(b)

Figure 12. (a) Permanent strain of asphalt mixtures under static loads; (b) Permanent strain of asphalt mixtures under dynamic loads [34].

Ziari et al. [44] used various PET particle sizes to assess the rutting performance of an asphalt mixture. The study noted that permanent deformation reduced when PET was added. Additionally, PET particles can absorb the stresses resulting from dynamic loads and delayed rutting deformation. El-naga and Ragab [47] employed a recycled PET as an additive to evaluate the rutting properties of an asphalt mixture. The results showed that any amount of PET used in asphalt mixtures would increase the pavement resistance to rutting damage. Moghaddam et al. [66] applied specialized software to assess the rutting properties of an asphalt mixture added with PET. The experimental and ANFIS-predicted Root-Mean-Squared Error (RMSE) were compared. It was noted that the PET content and environmental conditions greatly affect the rutting behavior of the asphalt mixture. Furthermore, accumulative strain decreased with the addition of PET to the asphalt mixture. Moreover, from the results, ANFIS was found more accurate for predicting the rutting deformation behavior of the asphalt mixture rather than experimental means.

Experiments have shown that using PET in SMA results in higher resistance to rutting deformation compared to dense-graded mixtures. It is due to the nature of its skeleton composition of coarse aggregate and a higher asphalt binder content, while at the same time offering stronger contact between the coarse aggregate. Furthermore, SMA has the ability to protect the mixture from repeated and heavy traffic loads and high pressure caused by vehicle tires [40,42]. In addition, the studies showed that using fine-graded of PET particles more significant performance than the coarse-graded PET particles [45]. The test results indicate that PET particles would absorb the generated stress caused by the increase in dynamic load which, results in a reduction in permanent deformation [44]. On the other hand, conventional test methods such as Marshall, strength and stiffness tests which previously used to evaluate the rutting deformation of the asphalt mixture considered not to be proper criteria for assessing the rutting behavior of the PET-modified asphalt mixture [34].

\subsection{Moisture Sensitivity of Asphalt Mixtures Containing PET}

Asphalt pavement failure occurs due to accumulated damage in the various layers of pavement construction. Moisture damage is considered a common cause of asphalt failure due to water seeps into the asphalt pavement structure $[67,68]$. This damage 
changes the mechanical properties of the pavement, resulting in reduced performance such as compromised strength, stiffness, and durability [69]. A material has good adhesion strength if it can withstand applied loading without failure. The adhesion strength of an asphalt mixture is determined from the binder used to bind its bitumen-aggregate structure [70]. Moisture damage usually occurs under two conditions: (i) when the asphalt binder becomes mastic, or cohesion occurs; and (ii) when the bitumen-aggregate adhesion reduces. Both conditions occur in the presence of water resulting in stripping phenomenon, which weakens the adhesion between the asphalt binder and the aggregate particles, and thus affecting the chemical composition and alliance of both. Thus, the individual properties of these materials, as well the properties of asphalt mixture, significantly impact of road pavement performance [71,72].

Several studies have shown that aggregate surface texture, aggregate porosity, aggregate cleanliness, aggregate absorption sites, aggregate energy, the chemistry of the asphalt binder, and the bonding and interaction between asphalt binder and aggregate greatly affect moisture susceptibility [73]. Furthermore, additive material with high surface energy could increase the surface energy of modified bitumen, thereby improving water resistance [74]. A summary of the moisture performance of asphalt mixture using PET waste as additive is shown in Table 5.

Table 5. Moisture performance of asphalt mixtures added with PET waste.

\begin{tabular}{|c|c|}
\hline Author/Year & Main Finding \\
\hline $\begin{array}{l}\text { Ahmadinia } \\
\text { et al. (2012) }\end{array}$ & $\begin{array}{l}\text { PET particles } 1.18 \mathrm{~mm} \text { with Portland Cement in (SMA); Indirect tensile strength test. Tensile strength } \\
\text { and TSR reduced when PET was added to the asphalt mixture. }\end{array}$ \\
\hline $\begin{array}{l}\text { Guru et al. } \\
\text { (2014) }\end{array}$ & $\begin{array}{l}\text { Viscous PET polyol (VPP) and liquid PET polyol (TLPP); Nicholson stripping test. The study showed } \\
\text { that anti-stripping resistance dramatically increased when VPP and TLPP were added to the } \\
\text { asphalt mixture. }\end{array}$ \\
\hline $\begin{array}{l}\text { Teherkhani } \\
\text { and Arshadi } \\
\quad \text { (2017) }\end{array}$ & $\begin{array}{l}\text { Fine-graded of PET particles }(0.297-0.595 \mathrm{~mm}) \text {; Coarse-graded of PET particles }(1.18-2.36 \mathrm{~mm}) \text {; } \\
\text { Indirect tensile strength test. The result observes that the addition of } 2 \% \text { PET increased TRS, and vice } \\
\text { versa. Adding fine PET particles to the asphalt mixture yielded lower TSR values than adding coarse } \\
\text { PET particles. The results showed that the TSR of the saturated mixtures was greater than the TSR of } \\
\text { traditional samples when added with higher PET content }(2-4 \%) \text {. The TSR with }(2-4 \%) \text { PET for all } \\
\text { mixtures was higher than the permissible limit. }\end{array}$ \\
\hline $\begin{array}{l}\text { Ameri and } \\
\text { Nasr (2017) }\end{array}$ & $\begin{array}{l}\text { Devulcanized PET and Portland Cement; Indirect tensile strength test. The result displays that the } \\
\text { moisture damage improved up to } 7.5 \% \text { but this improvement decreased with the addition of a higher } \\
\text { amount of PET. }\end{array}$ \\
\hline $\begin{array}{l}\text { Silva et al. } \\
\quad \text { (2017) }\end{array}$ & $\begin{array}{l}\text { Micronized PET; Indirect tensile strength test. The asphalt mixture moisture susceptibility was least } \\
\text { affected by the addition of micronized PET. }\end{array}$ \\
\hline $\begin{array}{l}\text { Padhan et al. } \\
\qquad(2018)\end{array}$ & $\begin{array}{l}\text { BHETA addition; BAET addition; Hot water stripping test. The resistance against moisture damage } \\
\text { increased with BAET addition but did not significantly improve when BHETA was added. }\end{array}$ \\
\hline
\end{tabular}

Ahmadinia et al. [40] assessed the moisture susceptibility of SMA mixtures modified with PET particles. The findings of the tensile strength test of the control mixture and PET-mixtures are displayed in Figure 13. The results show that the addition of PET in the asphalt mixture reduced the tensile strength and tensile strength ratio (TSR). This result is attributed to the properties of PET, which is a semi-crystalline material. After mixing with a binder, PET holds the binder on its surface and reduces the thickness of the asphalt film that coat aggregates. In turn, the resistance against moisture damage reduces. Taherkhani and Arshadi [45] concluded that PET modification caused antistripping effects. The improved resistance to moisture could be due to the impact of the PET stiffening the asphalt binder when adding in a lower amount. Furthermore, the resistance to moisture damage increased with the addition of a higher percentage of PET particles (up to $4 \%$ PET), resulting in decreased asphalt binder film thickness as shown in Figure 14. 


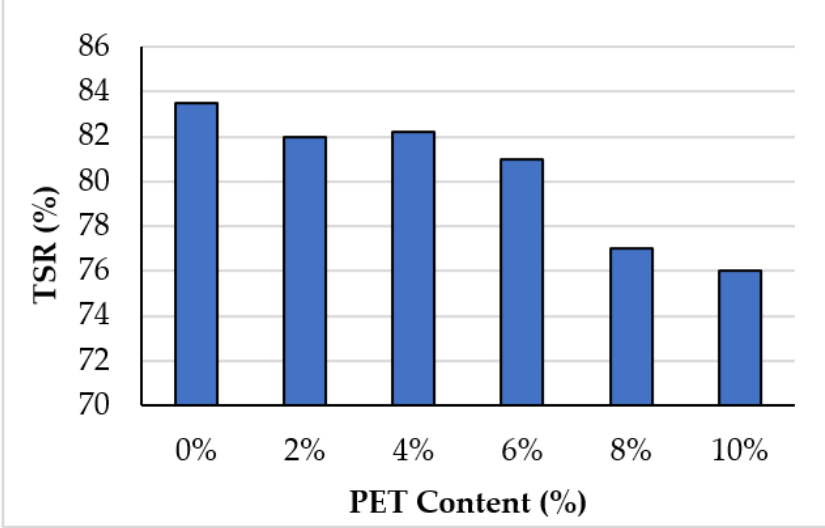

Figure 13. TSR of asphalt mixtures with different PET content [40].

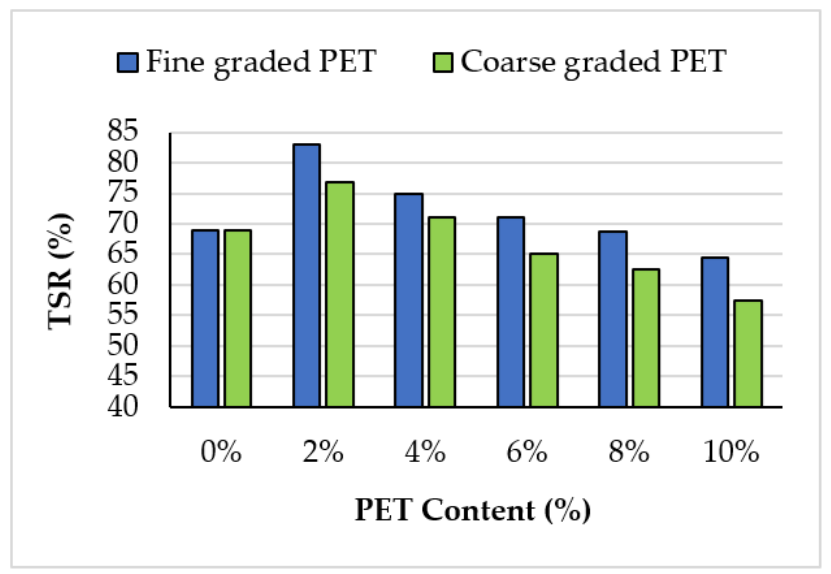

Figure 14. Tensile strength ratio versus PET content of the mixtures [45].

These findings agree with those of Ameri and Nasr [48], who showed that PET additive improved asphalt mixture resistance against moisture as seen in Figure 15, but the improvement decreased when a higher amount of PET was added, resulting in reduced asphalt binder workability.

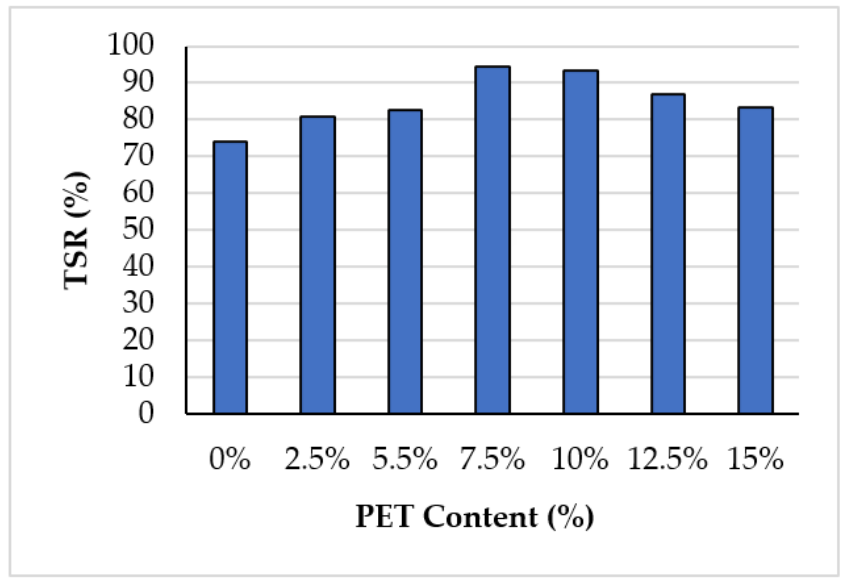

Figure 15. TSR of asphalt mixtures with different PET content [48].

Guru et al. [46] extracted viscous PET polyol (VPP) and liquid PET polyol (TLPP) from recycled PET and used both as an additive in asphalt mixtures. The study showed that the addition of VPP and TLPP in the asphalt mixture dramatically increased anti-stripping 
resistance. Additionally, Silva et al. [39] assessed a micronized PET-modified binder in HMA. The micronized PET had the least impact on moisture damage in asphalt mixtures, likely because the PET particles improved the mastic cohesion, via binder rheology, mechanical adhesion, and surface energy. On the other hand, Padhan et al. [49] evaluated the stripping resistance of an asphalt mixture using amine-based additives. The results showed that BAET significantly improved the resistance of the asphalt mixtures against stripping, thereby improving the adhesion strength between the aggregates and the binder, unlike the results with the addition of BHETA. This result shows that not all amine-based additives could improve the resistance of pavement moisture properties. That is, such properties could depend on the terminal functional group of the additive.

The mixtures that contain fine or coarse graded PET particles showed a higher value of TSR, this result indicates that PET could be used in the asphalt mixtures as an anti-stripping agent. The improvement in moisture resistance can also be attributed to the stiffening of PET modified asphalt mixture at lower PET contents. Furthermore, the ITS results decreased at higher PET contents due to the reduction of asphalt binder workability and the reduction in thickness of binder film that covered the aggregate, results in more damage caused by moisture $[45,48]$. On the other hand, the resistance to moisture damage is the least in PET modified asphalt mixtures, this might be due to the increase in cohesion of the mastic, mechanical adhesion, rheology of the filled binder, and surface energy [39].

\section{Future Research Work}

There is very limited work done so far on the chemical interaction between PET and asphalt binder which need to be analyzed further in detail to prove the true compatibility of material. The wet process can be further evaluated with the various gradation to analyze the performance of mixture as dry process has been followed so far. The dynamic rheological properties of the binder could be evaluated in accordance with the Strategic Highway Research Program (SHRP) to a better understanding of PET material. The modified binder can also be tested with short term ageing and long-term ageing. The development of proper modification method is needed to get optimum results for road construction as well as for industrial scale production. The nano sized PET is recommended to use in asphalt mixture as wet or dry process to further analyzed the mechanical performance of asphalt mixture.

\section{Conclusions}

The civil engineering field has increasingly applied recycled PET waste in pavement construction to reap the economic and environmental benefits. This article provided an overview of the benefits of reusing solid waste, such as PET waste, to benefit the asphalt pavement industry. The supply and demand for recycled PET could be leveraged to save costs and increase waste management efficiency. Besides, new projects could be established to enhance the commercial feasibility of PET waste for pavement construction. For example, high quality and eco-friendly asphalt pavements could be developed for the future. On the other hand, PET has a high melting point temperature of about $250{ }^{\circ} \mathrm{C}$, but if it is mixed with the asphalt binder via the wet process, PET will not maintain its homogeneity in the asphalt mixture. Thus, most studies used the dry process to add PET to asphalt mixtures. These studies focused on using recycled PET flakes in the asphalt mixture as fine aggregate replacement. The results showed increased resistance to rutting deformation and fatigue in the modified pavement compared to the unmodified ones. The studies conclude that replacing the aggregates in asphalt mixtures with PET particles could enhance the mechanical properties of the asphalt. Almost all studies reported that adding a lower proportion of PET ( $2-4 \%$ ) would result in better resistance against rutting. The addition of PET particles in asphalt mixtures also increased resistance to fatigue. Besides, lower PET content also caused better moisture resistance. Moreover, PET had a limited effect on moisture susceptibility. Generally, the results showed that using optimum PET proportions significantly enhanced the performance of pavement structures. Finally, using PET waste 
as an additive in asphalt mixtures could serve as an environmentally friendly method to dispose of PET waste while simultaneously producing high quality pavements.

Author Contributions: This article is the result of the joint work by all authors. Designing, carrying out and writing-original draft, M.M.B.Z.; review and editing F.M.J.; conceptualization and supervision F.M.J., R.M. and S.H. All authors have read and agreed to the published version of the manuscript.

Funding: This research received no external funding.

Conflicts of Interest: The authors declare no conflict of interest.

\section{References}

1. Geyer, R.; Jambeck, J.R.; Law, K.L. Production, use, and fate of all plastics ever made. Sci. Adv. 2017, 3, e1700782. [CrossRef] [PubMed]

2. Chidambarampadmavathy, K.; Karthikeyan, O.P.; Heimann, K. Sustainable bio-plastic production through landfill methane recycling. Renew. Sustain. Energy Rev. 2017, 71, 555-562. [CrossRef]

3. Khan, M.Z.H.; Sultana, M.; Al-Mamun, M.R.; Hasan, M.R. Pyrolytic Waste Plastic Oil and Its Diesel Blend: Fuel Characterization. J. Environ. Public Health 2016. [CrossRef] [PubMed]

4. Lebreton, L.; Andrady, A. Future scenarios of global plastic waste generation and disposal. Palgrave Commun. 2019. [CrossRef]

5. Tulashie, S.K.; Boadu, E.K.; Dapaah, S. Plastic waste to fuel via pyrolysis: A key way to solving the severe plastic waste problem in Ghana. Therm. Sci. Eng. Prog. 2019, 11, 417-424. [CrossRef]

6. Jambeck, J.R.; Geyer, R.; Wilcox, C.; Siegler, T.R.; Perryman, M.; Andrady, A.; Narayan, R.; Law, K.L. Plastic waste inputs from land into the ocean. Science 2015, 347, 768-771. [CrossRef]

7. Bajracharya, R.M.; Manalo, A.C.; Karunasena, W.; Lau, K.T. An overview of mechanical properties and durability of glass-fibre reinforced recycled mixed plastic waste composites. Mater. Des. 2014, 62, 98-112. [CrossRef]

8. Ragaert, K.; Delva, L.; Van Geem, K. Mechanical and chemical recycling of solid plastic waste. Waste Manag. 2017, 69, 24-58. [CrossRef]

9. Lazarevic, D.; Aoustin, E.; Buclet, N.; Brandt, N. Plastic waste management in the context of a European recycling society: Comparing results and uncertainties in a life cycle perspective. Resour. Conserv. Recycl. 2010, 55, 246-259. [CrossRef]

10. Al-Salem, S.M.; Lettieri, P.; Baeyens, J. Recycling and recovery routes of plastic solid waste (PSW): A review. Waste Manag. 2009, 29, 2625-2643. [CrossRef]

11. Chowdhury, G.W.; Koldewey, H.J.; Napper, I.E.; Niloy, N.H.; Sarah, E. Plastic Pollution in Aquatic Systems in Bangladesh: A Review Of Current Knowledge. Sci. Total Environ. 2020, 143285. [CrossRef] [PubMed]

12. Babafemi, A.J.; Šavija, B.; Paul, S.C.; Anggraini, V. Engineering Properties of Concrete with Waste Recycled Plastic: A Review. Sustainability 2018, 10, 3875. [CrossRef]

13. Singh, N.; Hui, D.; Singh, R.; Ahuja, I.P.S.; Feo, L.; Fraternali, F. Recycling of plastic solid waste: A state of art review and future applications. Compos. Part B Eng. 2017, 115, 409-422. [CrossRef]

14. Grigore, M.E. Methods of recycling, properties and applications of recycled thermoplastic polymers. Recycling 2017, 2, 24. [CrossRef]

15. Salazar-Beltrán, D.; Hinojosa-Reyes, L.; Palomino-Cabello, C.; Turnes-Palomino, G.; Hernández-Ramírez, A.; Guzmán-Mar, J.L. Determination of phthalate acid esters plasticizers in polyethylene terephthalate bottles and its correlation with some physicochemical properties. Polym. Test. 2018, 68, 87-94. [CrossRef]

16. Padhan, R.K.; Gupta, A.A.; Badoni, R.P.; Bhatnagar, A.K. Poly(ethylene terephthalate) waste derived chemicals as an antistripping additive for bitumen-An environment friendly approach for disposal of environmentally hazardous material. Polym. Degrad. Stab. 2013, 98, 2592-2601. [CrossRef]

17. Shukla, S.R.; Harad, A.M. Aminolysis of polyethylene terephthalate waste. Polym. Degrad. Stab. 2006, 91, 1850-1854. [CrossRef]

18. Marques, D.V.; Barcelos, R.L.; Parma, G.O.C.; Girotto, E.; Júnior, A.C.; Pereira, N.C.; Magnago, R.F. Recycled polyethylene terephthalate and aluminum anodizing sludge-based boards with flame resistance. Waste Manag. 2019, 92, 1-14. [CrossRef]

19. LI, W.C.; Tse, H.F.; Fok, L. Plastic waste in the marine environment: A review of sources, occurrence and effects. Sci. Total Environ. 2016, 566, 333-349. [CrossRef]

20. Mohammed, A.A. Flexural behavior and analysis of reinforced concrete beams made of recycled PET waste concrete. Constr. Build. Mater. 2017, 155, 593-604. [CrossRef]

21. Webb, H.K.; Arnott, J.; Crawford, R.J.; Ivanova, E.P. Plastic Degradation and its Environmental Implications with Special Reference to Poly(ethylene terephthalate). Polymers 2012, 5, 1-18. [CrossRef]

22. Raheem, A.B.; Noor, Z.Z.; Hassan, A.; Hamid, M.K.A.; Samsudin, S.A.; Sabeen, A.H. Current developments in chemical recycling of post-consumer polyethylene terephthalate wastes for new materials production: A review. J. Clean. Prod. 2019, 225, 1052-1064. [CrossRef]

23. Leng, Z.; Padhan, R.K.; Sreeram, A. Production of a sustainable paving material through chemical recycling of waste PET into crumb rubber modified asphalt. J. Clean. Prod. 2018, 180, 682-688. [CrossRef] 
24. Sinha, V.; Patel, M.R.; Patel, J.V. PET waste management by chemical recycling: A review. J. Polym. Environ. $2010,18,8-25$. [CrossRef]

25. Spychaj, T.; Fabrycy, E.; Spychaj, S.; Kacperski, M. Aminolysis and aminoglycolysis of waste poly(ethylene terephthalate). J. Mater. Cycles Waste Manag. 2001, 3, 24-31.

26. Parab, Y.S.; Wasekar, P.A.; Mhaske, S.T.; Shukla, S.R. Novel synthesis, characterization and application of dibutyrate bis(2hydroxyethyl) terephthalamide as a plasticizer in PVC compounding. Polym. Bull. 2014, 71, 2695-2707. [CrossRef]

27. Awaja, F.; Pavel, D. Recycling of PET. Eur. Polym. J. 2005, 41, 1453-1477. [CrossRef]

28. Farzi, A.; Dehnad, A.; Fotouhi, A.F. Biodegradation of polyethylene terephthalate waste using Streptomyces species and kinetic modeling of the process. Biocatal. Agric. Biotechnol. 2019, 17, 25-31. [CrossRef]

29. Tenza-abril, A.J.; Saval, M.; Eugenia, V.; Solak, A.M.; Real, T.; Ortega, M. Effects of Using Mine Tailings from La Uni ó n (Spain) in Hot Bituminous Mixes Design. Appl. Sci. 2019, 9, 272. [CrossRef]

30. Muniandy, R.; Aburkaba, E. The effect of type and particle size of industrial wastes filler on Indirect Tensile Stiffness and Fatigue performance of Stone Mastic Asphalt Mixtures. Aust. J. Basic Appl. Sci. 2011, 5, 297-308.

31. Tahmoorian, F.; Samali, B.; Yeaman, J.; Crabb, R. The use of glass to optimize bitumen absorption of hot mix asphalt containing recycled construction Aggregates. Materials 2018, 11, 1053. [CrossRef] [PubMed]

32. De Melo, J.V.S.; Trichês, G. Evaluation of properties and fatigue life estimation of asphalt mixture modified by organophilic nanoclay. Constr. Build. Mater. 2017, 140, 364-373. [CrossRef]

33. Mashaan, N.S.; Ali, A.H.; Karim, M.R.; Abdelaziz, M. A Review on Using Crumb Rubber in Reinforcement of Asphalt Pavement. Sci. World J. 2014. [CrossRef] [PubMed]

34. Moghaddam, T.B.; Soltani, M.; Karim, M.R. Experimental characterization of rutting performance of Polyethylene Terephthalate modified asphalt mixtures under static and dynamic loads. Constr. Build. Mater. 2014, 65, 487-494. [CrossRef]

35. Ahmadinia, E.; Zargar, M.; Karim, M.R.; Abdelaziz, M.; Shafigh, P. Using waste plastic bottles as additive for stone mastic asphalt. Mater. Des. 2011, 32, 4844-4849. [CrossRef]

36. Moghaddam, T.B.; Karim, M.R.; Syammaun, T. Dynamic properties of stone mastic asphalt mixtures containing waste plastic bottles. Constr. Build. Mater. 2012, 34, 236-242. [CrossRef]

37. Rodrigues, G.; Carvalho, M.W.; Costa, D.B. Use of Micronized Polyethylene Terephthalate (Pet) Waste in Asphalt Binder Use of Micronized Polyethylene Terephthalate (Pet) Waste in Asphalt Binder. Pet. Sci. Technol. 2015, 33, 1508-1515. [CrossRef]

38. Modarres, A.; Hamedi, H. Effect of waste plastic bottles on the stiffness and fatigue properties of modified asphalt mixes. Mater. Des. 2014, 61, 8-15. [CrossRef]

39. De Arimateia Almeida e Silva, J.; Rodrigues, J.K.G.; de Carvalho, M.W.; de Figueredo Lopes Lucena, L.C.; Cavalcante, E.H. Mechanical performance of asphalt mixtures using polymer-micronized PET-modified binder. Road Mater. Pavement Des. 2018, 19, 1001-1009.

40. Ahmadinia, E.; Zargar, M.; Karim, M.R.; Abdelaziz, M.; Ahmadinia, E. Performance evaluation of utilization of waste Polyethylene Terephthalate (PET) in stone mastic asphalt. Constr. Build. Mater. 2012, 36, 984-989. [CrossRef]

41. Moghaddam, T.B.; Karim, M.R.; Soltani, M. Utilization of waste plastic bottles in asphalt mixture. J. Eng. Sci. Technol. 2013, 8, 264-271.

42. Moghaddam, T.B.; Soltani, M.; Karim, M.R. Evaluation of permanent deformation characteristics of unmodified and Polyethylene Terephthalate modified asphalt mixtures using dynamic creep test. Mater. Des. 2014, 53, 317-324. [CrossRef]

43. Dehghan, Z.; Modarres, A. Evaluating the fatigue properties of hot mix asphalt reinforced by recycled PET fibers using 4-point bending test. Constr. Build. Mater. 2017, 139, 384-393. [CrossRef]

44. Ziari, H.; Kaliji, A.G.; Babagoli, R. Laboratory evaluation of the effect of waste plastic bottle (\{PET $\})$ on rutting performance of hot mix asphalt mixtures. Pet. Sci. Technol. 2016, 34, 819-823. [CrossRef]

45. Taherkhani, H.; Arshadi, M.R. Investigating the mechanical properties of asphalt concrete containing waste polyethylene terephthalate. Road Mater. Pavement Des. 2019, 20, 381-398. [CrossRef]

46. Gürü, M.; Çubuk, M.K.; Arslan, D.; Farzanian, S.A.; Bilici, İ. An approach to the usage of polyethylene terephthalate (PET) waste as roadway pavement material. J. Hazard. Mater. 2014, 279, 302-310. [CrossRef]

47. El-Naga, I.A.; Ragab, M. Benefits of utilization the recycle polyethylene terephthalate waste plastic materials as a modifier to asphalt mixtures. Constr. Build. Mater. 2019, 219, 81-90. [CrossRef]

48. Ameri, M.; Nasr, D. Performance properties of devulcanized waste PET modified asphalt mixtures. Pet. Sci. Technol. 2017, 35, 99-104. [CrossRef]

49. Padhan, R.K.; Mohanta, C.; Sreeram, A.; Gupta, A. Rheological evaluation of bitumen modified using antistripping additives synthesised from waste polyethylene terephthalate (PET). Int. J. Pavement Eng. 2018, 1-9. [CrossRef]

50. Rahman, W.M.; Wahab, A.F.A. Green Pavement using Recycled Polyethylene Terephthalate (PET) as Partial Fine Aggregate Replacement in Modified Asphalt. Procedia Eng. 2013, 53, 124-128. [CrossRef]

51. Ameri, M.; Nasr, D. Properties of asphalt modified with devulcanized polyethylene terephthalate. Pet. Sci. Technol. 2016, 34, 1424-1430. [CrossRef]

52. Cui, P.; Xiao, Y.; Fang, M.; Chen, Z.; Yi, M.; Li, M. Residual Fatigue Properties of Asphalt Pavement. Materials $2018,11,892$. [CrossRef] [PubMed] 
53. Muniandy, R.; Akhir, N.A.B.C.M.; Hassim, S.; Moazami, D. Laboratory fatigue evaluation of modified and unmodified asphalt binders in stone mastic asphalt mixtures using a newly developed crack meander technique. Int. J. Fatigue 2014, 59, 1-8. [CrossRef]

54. Wu, S.; Wen, H.; Zhang, W.; Shen, S.; Mohammad, L.N.; Faheem, A.; Muhunthan, B. Field performance of top-down fatigue cracking for warm mix asphalt pavements. Int. J. Pavement Eng. 2019, 20, 33-43. [CrossRef]

55. Bańkowski, W. Evaluation of Fatigue Life of Asphalt Concrete Mixtures with Reclaimed Asphalt Pavement. Appl. Sci. 2018, 8, 469. [CrossRef]

56. Khattak, M.J.; Baladi, G.Y. Fatigue and permanent deformation models for polymer-modified asphalt mixtures. Transp. Res. Rec. 2001, 1767, 135-145. [CrossRef]

57. Park, H.J.; Kim, Y.R. Primary causes of cracking of asphalt pavement in North Carolina: Field study. Int. J. Pavement Eng. 2015, 16, 684-698. [CrossRef]

58. Rahman, W.M.N.W.A.; Omardin, M.A. characterisation of recycled polyethylene terephthalate as partial fine aggregate replacement properties and behaviour of asphalt mixtures for road pavements. Arpn J. Eng. Appl. Sci. 2016, 11, 3755-3758.

59. Lv, Q.; Huang, W.; Sadek, H.; Xiao, F.; Yan, C. Investigation of the rutting performance of various modified asphalt mixtures using the Hamburg Wheel-Tracking Device test and Multiple Stress Creep Recovery test. Constr. Build. Mater. 2019, 206, 62-70. [CrossRef]

60. Radziszewski, P. Modified asphalt mixtures resistance to permanent deformations. J. Civ. Eng. Manag. 2007, 13, 307-315. [CrossRef]

61. Babagoli, R.; Ziari, H. Evaluation of rutting performance of stone matrix asphalt mixtures containing warm mix additives. J. Cent. South Univ. 2017, 24, 360-373.

62. Morea, F.; Agnusdei, J.O.; Zerbino, R. The use of asphalt low shear viscosity to predict permanent deformation performance of asphalt concrete. Mater. Struct. 2011, 44, 1241-1248. [CrossRef]

63. Ji, X.; Zheng, N.; Hou, Y.; Niu, S. Application of asphalt mixture shear strength to evaluate pavement rutting with accelerated loading facility (ALF). Constr. Build. Mater. 2013, 41, 1-8. [CrossRef]

64. Id, J.R.; Kamal, M.A.; Ahmad, N.; Hafeez, M.; Faizan, M.; Asif, S.A.; Shabbir, F.; Bilal Ahmed Zaidi, S. Performance Evaluation of Carbon Black Nano-Particle Reinforced Asphalt Mixture. Appl. Sci. 2018, 8, 1114. [CrossRef]

65. Harvey, J.; Weissman, S.; Long, F.; Monismith, C. Tests to evaluate the stiffness and permanent deformation characteristics of asphalt/binder-aggregate mixes, and their use in mix design and analysis (with discussion). J. Assoc. Asph. Paving Technol. 2001, $70,572-604$.

66. Moghaddam, T.B.; Soltani, M.; Karim, M.R.; Shamshirband, S.; Petković, D.; Baaj, H. Estimation of the rutting performance of Polyethylene Terephthalate modified asphalt mixtures by adaptive neuro-fuzzy methodology. Constr. Build. Mater. 2015, 96, 550-555. [CrossRef]

67. Hamzah, M.O.; Kakar, M.R.; Quadri, S.A.; Valentin, J. Quantification of moisture sensitivity of warm mix asphalt using image analysis technique. J. Clean. Prod. 2014, 68, 200-208. [CrossRef]

68. Wang, W.; Wang, L.; Xiong, H.; Luo, R. A review and perspective for research on moisture damage in asphalt pavement induced by dynamic pore water pressure. Constr. Build. Mater. 2019, 204, 631-642. [CrossRef]

69. Yao, Z.; Zhu, H.; Gong, M.; Yang, J.; Xu, G.; Zhong, Y. Characterization of asphalt materials' moisture susceptibility using multiple methods. Constr. Build. Mater. 2017, 155, 286-295. [CrossRef]

70. Omar, H.A.; Yusoff, N.I.M.; Ceylan, H.; Sajuri, Z.; Jakarni, F.M.; Ismail, A. Investigation of the relationship between fluidity and adhesion strength of unmodified and modified bitumens using the pull-off test method. Constr. Build. Mater. 2016, 122, 140-148. [CrossRef]

71. Rosli, M.F.; Jakarni, F.M.; Yusoff, N.I.M. Moisture Damage Performance Tests of Asphalt Mixtures: A Review. J. Ind. Eng. Res. 2015, 1, 7-15.

72. Haider, S.; Hafeez, I.; Zaidi, S.B.A.; Nasir, M.A.; Rizwan, M. A pure case study on moisture sensitivity assessment using tests on both loose and compacted asphalt mixture. Constr. Build. Mater. 2020, 239, 117817. [CrossRef]

73. Abo-Qudais, S.; Al-Shweily, H. Effect of aggregate properties on asphalt mixtures stripping and creep behavior. Constr. Build. Mater. 2007, 21, 1886-1898. [CrossRef]

74. Omar, H.A.; Yusoff, N.I.M.; Ceylan, H.; Rahman, I.A.; Sajuri, Z.; Jakarni, F.M.; Ismail, A. Determining the water damage resistance of nano-clay modified bitumens using the indirect tensile strength and surface free energy methods. Constr. Build. Mater. 2018, 167, 391-402. [CrossRef] 